Language in Africa 1(4), 2020, 226-244. doi: 10.37892/2686-8946-2020-1-4-226-244

\title{
ABSOLUTE-RELATIVE TENSE IN OLD KANEMBU: FOREGROUNDING BY POSTERIOR TAXIS
}

\author{
Dmitry Bondarev \\ University of Hamburg \\ dmitry.bondarev@uni-hamburg.de
}

\begin{abstract}
Old Kanembu is an extinct Saharan language that survives in annotations to the Qur'anic manuscripts of the $17^{\text {th }}$ to $18^{\text {th }}$ century. The past and future categories of Old Kanembu are absolute-relative tenses with posterior taxis as their orientational mechanism. The posterior location of events in temporal domains is tied up with the communicative goal of guiding the recipient through the complex Qur'anic discourse so that the foreground information and prominent elements are clearly set off against the background events. Similar properties are reported for the past and future tenses in Kanuri and therefore the Old Kanembu data corroborates a previously postulated hypothesis that the past and future in Kanuri are inherently focus categories (Wolff \& Löhr 2006). Given that complexity of the Kanuri TAM system - significantly more elaborated than in the other Saharan languages - was triggered by the contact with Chadic languages and that Old Kanembu preserves archaic features going back to the $16^{\text {th }}$ century and beyond, the semantic properties of the Old Kanembu past and future provide additional evidence of early Chadic influence on Kanuri.
\end{abstract}

Key words: Old Kanembu, Kanuri, West Chadic, information structure, foregrounding, focus, past tense, future tense, absolute-relative tense, taxis

\section{Introduction}

Old Kanembu (OKb) is an extinct Saharan language that survives in annotations to the Qur'anic manuscripts of the $17^{\text {th }}$ to $18^{\text {th }}$ century. It preserves Saharan linguistic structures significantly predating the actual manuscripts, probably going back to the period between the $13^{\text {th }}$ and $16^{\text {th }}$ centuries. $\mathrm{OKb}$ has its direct descendent in a liturgical language called Tarjumo which is used by Kanuri-speaking Islamic clerics of 
present-day Borno, Nigeria, for highly specialised translation of the Qur'an and other Arabic texts. As conservative linguistic codes, both $\mathrm{OKb}$ and Tarjumo represent older linguistic layers unattested in Kanuri, which render them unintelligible to Kanuri speakers. However, when compared to $\mathrm{OKb}$, Tarjumo is somewhat closer to the Kanuri linguistic structures (Bondarev 2005; 2013a; 2013b; 2014a). Kanuri - referred to here as Modern Kanuri (MK) to distinguish it from $\mathrm{OKb}$ and Tarjumo - is a cover term for two dialect clusters, Kanuri and Kanembu. Kanembu dialects are spoken on the northeastern shores of Lake Chad (about 500,000 speakers) and Kanuri dialects are spoken on vast territories on the other side of the Lake (about 3.5 million speakers).

$\mathrm{OKb}$ texts are multi-layered translations of the complex Qur'anic discourse, where utterances and narrated events are entangled in intricate deictic and temporal configurations, reminiscent of "situations of layered speech" (Timberlake 2007: 310). OKb follows the Qur'an text with meticulous attention to both the Arabic grammatical structures and the events in the narrative. Lexical influence of Arabic on $\mathrm{OKb}$ is significant, but syntax and morphology are largely indigenous and exhibit cross-Saharan features. What sets $\mathrm{OKb}$ (and $\mathrm{MK}$ ) apart from the rest of Saharan is elaborate verbal TAM categories. OKb (like MK) has fifteen canonical and non-canonical inflectional and four derivational categories which are applied in full range to convey contextual information and deictic, aspectual and temporal configuration of utterances and events. The past and future tenses are two such $\mathrm{OKb}$ categories. Their temporal and deictic frames establish posterior taxis. The main claim of this paper is that the $\mathrm{OKb}$ past and future are absolute-relative tenses with posterior taxis as their orientational mechanism. The posterior location of events in temporal domains is tied up with the communicative goal of guiding the recipient through the complex Qur'anic discourse so that the foreground information and prominent elements are clearly set off against the background events.

Similar properties are reported for the past and future categories in $\mathrm{MK}$ and in some contact Chadic languages. This brings the $\mathrm{OKb}$ past and future in line with the previous analysis of the MK tense 
categories as having intrinsic focus property (Wolff \& Löhr 2006). ${ }^{1}$ The present treatment of these $\mathrm{OKb}$ categories as foregrounding devices is also informed by a unified analysis of the Hausa focus-perfective/ narrative-perfective category (Jaggar 2006).

The following section $(\S 2)$ gives relevant definitions, $\S 3$ presents temporal semantics of $\mathrm{OKb}$ past and future in different syntactic environment, $\S 4$ compares $\mathrm{OKb}$ past and future forms with their cognate forms in MK dialects and looks into the properties of past and future in MK. Finally, $\S 5$ briefly compares the findings with the similar phenomena in some Chadic languages and $\$ 6$ gives a summary and a conclusion.

\section{Definitions}

The Qur'an is abundant with direct and reported speech discourse. In translation and explications of both direct $(\mathrm{X})$ and reported $(\mathrm{Y})$ speech, $\mathrm{OKb}$ glosses are often framed in quotative construction (he said $X / Y$ ) or imperative $($ say $X / Y$ !). Control of sequence of events embedded into the syntactic hierarchy of phrases and clauses is thus essential for $\mathrm{OKb}$ translations. To understand distribution of $\mathrm{OKb}$ verbal categories in this layered speech, it is necessary to define what constitutes a deictic centre for any given verb form. Time of speech/present moment would not be very useful because of the ambiguity of the "present moment" during the recitation and translation of the Qur'an and because of a recursive and intertwined nature of the reported events (God reveals a complex message to Muhammad via Gabriel, but the revealed utterances are further interpreted by exegetic tradition, prompting even more complex packaging of the translated outcome). This has bearing on the definition of absolute tense. It is not just a category that "specifies

${ }^{1}$ As defined by Hyman \& Watters (1984), intrinsic, or inherent, focus refers to grammatical (rather than pragmatical) focus control occasioned by a grammatical category that has its own (intrinsic/inherent) focus semantics. Also see Wolff (2005) on intrinsic focus in Hausa. 
the present moment as reference point" (Comrie 1985: 58), but rather a category that establishes a "temporal domain in one of the absolute sectors" such as past versus non-past (Declerck 1995: 6).

A deictic centre in any $\mathrm{OKb}$ data is thus a timeless "revelation/ narration" anchor-point. The events located within the temporal domains (established by absolute tenses) are related to each other by relative tenses, which do not specify the deictic centre/present moment as reference point (Comrie 1985). The same orientation of events relative to each other is also known as taxis (Jakobson 1984: 46; Maslov 1988: 64; Güldemann 1998), and "relative tense" and "taxis" are sometimes used interchangeably (Timberlake 2007: 308). Since this paper deals with absolute-relative tense it is useful to avoid potential confusion between relative tense and absolute-relative tense. ${ }^{2}$ Therefore, I will describe relative orientation of events in terms of taxis, whereas chronological orientation of events both in relation to each other and to a deictic point will be described in terms of absolute-relative tense.

By Comrie's analysis, which I follow here, "absolute-relative tenses are determined by a reference point being before or after the present moment, and by the situation being located before or after that reference point" (1985: 64). The absolute-relative tenses discussed in OKb are absolute-relative past (ARP) and absolute-relative future (ARF). Since they both locate a situation by way of posterior taxis, that is after a reference point, they fall under the tense-type of "future in the past" and "future in the future" respectively (Comrie 1985: 74-75). Using a combination of schematic representation by Declerck 1995 and in line with Comrie's analysis of absolute-relative tense, $\mathrm{OKb}$ absoluterelative tenses can schematically be represented as follows: ARP = R-E-S, which reads "event/situation (E) is located after a refence point

${ }^{2}$ For example, Maslov (1988: 64) applies the notion of relative tense to strictly speaking absolute-relative tenses: "In other languages tense pairs up with taxis in the forms of so-called relative tenses (doubly oriented tenses, like the pluperfect or future in the past)" (emphasis added). 
(R) and before the moment of speech/deictic centre (S)". ARF = S-R-E, which reads "event/situation (E) is located after a refence point (R) and after the moment of speech/deictic centre (S)".

\section{Past and future in Old Kanembu}

\subsection{Absolute tense expressed by the perfective and imperfective}

In $\mathrm{OKb}$, absolute tenses are expressed by perfective and imperfective forms cognate with other Saharan perfective/imperfective categories. The forms are signalled by segmentally identical suffix $-i$ and are only distinguished by tone (suprasegmental tonal values of the perfective and imperfective are usually underspecified in $\mathrm{OKb}$ ) (Bondarev 2005). The examples below profile the occurrences of $\mathrm{OKb}$ perfective and imperfective in their default absolute tense semantics. The alphanumeric code preceding each example of $\mathrm{OKb}$ data indicates a manuscript/ section of the Qur'an. All $\mathrm{OKb}$ data are transliterated from Arabic script and given in graphemic representation.

(1) $(\mathrm{YM} / 80: 1)$ Past time reference.

fska mr- $\theta-\bar{\imath} \quad$ me-s-i
face frown-3SG-PFV turn.away-3SG-PFV
'He frowned and turned away.'
(YM/41:53). Future time reference.
andiye tandiro $\quad$ irk-flā-y
1PL.SBJ 3PL.IO APPL-show-1PL.IPFV
'We will show them (Our sings).'

\subsection{Absolute-relative tense expressed by the past and future}

The morphology of past and future forms (that express absolute-relative semantics) is more complex. Both categories share the same suffix -0 , graphemically represented as $\langle\overline{\mathrm{u}} / \mathrm{u}>$ in manuscripts, but analysed as /o/ (Bondarev 2014b). Past tense is formed with a prefix $k$ - and future 
tense with a prefix $t$-. In 3rd person singular and plural forms, the $\mathrm{OKb}$ class III/IV verbs have a suffix - no (written as $<\mathrm{nu} / \mathrm{nu}>$ ). ${ }^{3}$

OKb Past:

(3) $(\mathrm{YM} / 2: 72) \boldsymbol{k} \boldsymbol{e}-\mathrm{j} \bar{\imath}-y-\overline{\boldsymbol{u}}$

'(then) you killed (someone)'

(PST-kill-2PL-AFP)

(4) (YM/3:167) guljāy-nū

'(then) they said'

(say.3PL.PST-no)

$\mathrm{OKb}$ Future:

(5) $(\mathrm{YM} / 4: 61) \boldsymbol{\theta} \overline{\mathbf{i}}-r \bar{u}-m-\boldsymbol{u}$

'You will see.'

(FUT-See-2SG-AFP)

(6) $(\mathrm{YM} / 81: 1)$ waqaSäi-nū

'He will make it happen.'

(make.happen.3sG.FUT-no)

The $\mathrm{OKb}$ past and future are cognate with the equivalent tenses in $\mathrm{MK}$. Both categories (in $\mathrm{OKb}$ and $\mathrm{MK}$ ) derive from the focus perfective verb form $-o$, which I call here argument focus perfective (AFP) (for alternative terminology see Wolff \& Löhr 2006:190). In OKb, this category is activated by focused arguments of the verbal predicates (wh-questions, new information, foregrounded and prominent elements). In MK this category exclusively operates on focused core arguments. By Wolff \& Löhr (2006) analysis, the inherent focus property of AFP has been carried over to MK past and future forms. The contextual uses of the $\mathrm{OKb}$ past and future forms prove to be consistent with their hypothesis. As the examples of the OKb ARP/ARF in the next section demonstrate, chronological placement of events after a reference point entails that thus encoded events are prominent foreground entities of the discourse at both sentence-internal and intersentential level.

${ }^{3} \mathrm{OKb}$ and $\mathrm{MK}$ have various inflectional and derivational patterns conditioned by the morphological class of the verb. Except for $\$ 4.1$, verbal classes are left unmarked since their distinction is not relevant for the purpose of this paper. 


\subsection{Past and future in Old Kanembu: meaning and function}

The past and future forms are mostly used to locate events after a reference point in the past or future. These forms occur in three types of restricted environment, as follows.

I. Matrix clause (apodosis) of conditional (if/when) constructions. Typically, describing the events posterior to a reference point established by the subordinate adverbial clause (temporal or conditional).

(7) $(\mathrm{YM} / 81: 1)$

kngālbe nrye kōkōtiya

sun.GEN light.SBJ lock.PASs.3sG.COND

qiyama waqaSatmaye waqaSäinū

Judgment Day happen.vN.AG.SBJ make.happen.3sG.ARF

'When the light of the sun will be locked, the Judgment Day will be brought by the One who makes it happen.'

(8) $(\mathrm{YM} / 45: 32)$

allahabe wasdtī jīrē gultiya sā?a

God.GEN promise. DET truth say.PASS.3sG.COND hour qiyamāt tigen shak bākū tandiye gulsinū Judgment.Day.DET 3sG.INESS doubt NEG 3PL.SBJ say.3SG.ARP 'When it was said that the promise of God is truth and there is no doubt about the Judgement Day, they said...'

II. Narrative foregrounding. The verbs of simple or coordinated clauses describing the events occurring after a reference point, usually introduced by connective anaphoric adjuncts such as 'then', 'and after that', etc.

(9) (YM/79:10-12) Context: (Abdel Haleem 2005: 407) “(79:10) They say, "What? Shall we be brought back to life, (79:11) after we have turned into decaying bones?" (79:12) and they say, "Such a return is impossible!'"' (Note that although there is no 'and' in the Qur'an, the verb of speech 'say' (PRF in Arabic and ARP in OKb) follows the question.) 
Oatadikiya

1 PL.OBJ.be.3 SG.COND

kttwalkrē

return.vN.TAG

After we hav shila dintbūro tadikiya

bone old.vN.PL.IO PASs.be.3SG.COND

$\begin{array}{lllll}\text { tandiye } & \text { gulsinū } & \text { atya } & \text { waltrk } & \text { hitbe } \\ \text { 3PL.SBJ } & \text { Say.3PL.ARP } & \text { this } & \text { return.PASS.CAUS } & \text { destruction.GEN } \\ \text { șahibuk } & & & & \end{array}$

type

'And they said that such a return is equal to destruction.'

(10) $(\mathrm{YM} / 78: 5)$

klēe fukēe tandìi tasndogō

then future 3PL.SBJ know.3SG.ARF

'Then they will know.'

III. Wh-constructions. The past tense is also used in focused wh(adverbial) constructions.

(11) (YM/80:18) Context: 'from what substance did He create him?' (Sahih International)

agō datū tika xalq-kinū

thing which 3SG.DO create-3SG.ARP

'From what did He create him?'

That the form in (11) is past rather than an AFP is supported by evidence from Tarjumo where the same Qur'anic phrase is translated by a cognate verbal form: alakono 'he created'.

(12) Tarjumo (80:18)

$\begin{array}{lll}\text { awowin } & \text { tika } & \text { ala-kono } \\ \text { thing.which } & \text { 3SG.DO } & \text { create-3SG.ARP }\end{array}$

'From what did He create him?' 
In (11) and (12), the choice of ARP is most likely motivated by the discourse necessity to locate the event in the past domain, signalling that man's creation happened following God's will.

Thus, the OKb ARP and ARF appear within the established temporal domains in (I) matrix verbs of conditional constructions, (II) narrative foregrounding as a strategy for tracking specific events and (III) in wh-questions (but only ARP). Although these types of syntactic, semantic and pragmatic environment may appear unrelated, they all share a 'posterior taxis' property by anaphorically referring to the events that condition or precede the realisation of the events encoded by ARP/ ARF. Importantly, these are all focused environments. Borrowing Philip Jaggar's description of a similar phenomenon in Hausa, "they all supply the most communicatively PROMINENT and focal NEW information and so achieve the same discourse-pragmatic goals" (Jaggar 2006: 107; emphasis in the original).

\section{Past and future in Modern Kanuri}

\subsection{Diagnostic forms}

The past and future tense forms in $\mathrm{OKb}$ are cognate with those in Kanuri and closely related Kanembu dialects. ${ }^{4}$ A diagnostic feature of these categories is suffix - no in $3^{\text {rd }}$ person forms of MK verb class 2 (and in Dagora dialect also class 1). The suffixing pattern fully matches the inflectional paradigm of the past/future and argument focus perfective (AFP) in Dagəra, Mowar and Tumari dialects (where -no occurs in both $3^{\text {rd }}$ singular and $3^{\text {rd }}$ plural forms) and partially pattern

${ }^{4}$ One of the anonymous reviewers suggested that I should explain why the $\mathrm{OKb}$ data have been compared with that of MK rather than Tarjumo. A comparison of $\mathrm{OKb}$ with Tarjumo would give insights into the development of the liturgical register represented by both. Since the conservative OKb preserves earlier stages of Kanuri, its comparison with MK yields insights into the history of MK. Equally, some $\mathrm{OKb}$ structures are better understood when they are compared with $\mathrm{MK}$ and its dialectal data, as this paper tries to demonstrate. 
with paradigm in Bilma (where -no only occurs in $3^{\text {rd }}$ singular in past/ future and AFP) and Manga and Yerwa (where -no is only used in $3^{\text {rd }}$ singular in past/future). All examples in Table 1 are from (Jarrett \& Maman 2004, henceforth J\&M).

Table 1

Verbal paradigms

\begin{tabular}{|c|c|c|c|c|c|}
\hline \multicolumn{3}{|c|}{ Dagəra } & \multicolumn{2}{|c|}{ Mowar } & Tumari \\
\hline $\begin{array}{l}\text { Class 1, 'sell' } \\
\text { (J\&M:125) } \\
\text { AFP } \\
\text { 3sG calado / } \\
\text { caladu-no } \\
\text { 3PL calado / } \\
\text { caladu-no } \\
\text { Past/Future } \\
\text { 3sG kilado / } \\
\text { kiladu-no } \\
\text { 3PL kelado / } \\
\text { keladu-no }\end{array}$ & \multicolumn{2}{|c|}{$\begin{array}{l}\text { Class } 2 \text { 'stay; } \\
\text { stop' } \\
\text { AFP (J\&M:155) } \\
\text { 3sG dazo / } \\
\text { dazu-no } \\
\text { 3PL daza / } \\
\text { daza-no } \\
\text { Past/Future } \\
\text { (J\&M:156) } \\
\text { 3sg daye-n } \\
\text { 3PL daye-ra }\end{array}$} & \multicolumn{2}{|c|}{$\begin{array}{l}\text { Class } 2 \text { 'stay; stop' } \\
\text { AFP(J\&M:340) } \\
\text { 3SG dayo / } \\
\text { dayi-no / } \\
\text { daya 3PL daya / } \\
\text { dayei-no } \\
\text { Past/Future } \\
\text { (J\&M:341) } \\
\text { 3SG daa-no } \\
\text { 3PL dayada / } \\
\text { dayei-no }\end{array}$} & $\begin{array}{l}\text { Class } 2 \text { 'stay; } \\
\text { stop' } \\
\text { AFP (J\&M:426) } \\
\text { 3sG dayi-no } \\
\text { 3PL daya-no } \\
\text { Past/Future } \\
\text { (J\&M:427) } \\
\text { 3sG daa-no } \\
\text { 3PL dagai-no }\end{array}$ \\
\hline \multicolumn{2}{|c|}{ Bilma } & \multicolumn{2}{|c|}{ Manga } & \multicolumn{2}{|r|}{ Yerwa } \\
\hline \multicolumn{2}{|c|}{$\begin{array}{l}\text { Class } 2 \text { 'stay; stop’ } \\
\text { AFP (J\&M:77) } \\
\text { 3sG daa-no } \\
\text { Past/Future (J\&M:78) } \\
\text { 3sG daa-no }\end{array}$} & \multicolumn{2}{|c|}{$\begin{array}{l}\text { Class } 2 \text { 'stay; stop' } \\
\text { Past/Future } \\
\text { (J\&M:238) } \\
\text { 3sg daye-no }\end{array}$} & \multicolumn{2}{|c|}{$\begin{array}{l}\text { Class } 2 \text { 'stay; stop' } \\
\text { Past } \\
\text { 3sg dawô-no } \\
\text { Future } \\
\text { 3sg dajô-no }\end{array}$} \\
\hline
\end{tabular}

\subsection{Syntactic, semantic and pragmatic properties of past and future in Modern Kanuri}

In MK, past and future forms show properties similar to the $\mathrm{OKb}$ ARP and ARF. They both flag foreground events which are contingent upon the established background. Without evoking the notion of focus, this peculiarity of MK past and future has long been reported in 
literature. Hutchison's (1981: 124) observations about the past form's syntactic dependence and entailment of semantic prominence are instructive:

A past verb form rarely occurs alone sententially, without some other sentence material preceding it. The use of the past entails there being some other major (nominal) or oblique (adverbial) constituent which semantically bears prominence over the action of the verb in a given utterance. (my italics - D.B.)

The past is also used in narratives (Lukas 1937: 36; Schubert 1971-1973; Cyffer 1973; Schuh 1976: 13 on Manga Kanuri: "completive aspect used in narratives"). Similar to the OKb ARP function of connecting previous background situations with coordinated foreground events, the MK past is a prototypical device in narratives.

In some pragmatic and lexically-specific contexts, the MK past tense is triggered by adverbial wh-questions. This is the case with the verbs describing atelic states 'live', 'stay', 'seat', etc. In most of the situations, these verbs are used in perfective. However, when the state is assumed to be a result of a preceding situation, it is the past tense that is obligatory required. This is illustrated in the following two examples.

(13) a. mónde ndarân kargâm? 'Where did you stay last year?' last year where stay.2sG.PST

ngúro ádglan kargáko 'I stayed in this ward.'

ward this.Loc stay.1SG.PST

b. ndarân kargâm? 'Where are you staying?'

where stay.2SG.PST

Hotel Vorbachlan kargáko 'I am staying in Vorbach Hotel.' Hotel Vorbach.LOC stay.1SG.PST

In (13a), the MK past cooccurs with past tense reference (introduced by mónde 'last year') and the stative situation in the past does not 
presuppose any preceding event. In (13b), however, it is not the state in the past, nor is it in the present that is encoded here, but rather a result after a journey (i.e. 'having arrived in the town, I am staying in Vorbach Hotel').

Striking similarity is also observed between the OKb ARF and MK future as in both languages the future is used in matrix verbs of conditional clauses. The future in MK is infrequent in everyday speech but most common in proverbs and common fixed and gnomic expressions (Hutchison 1981: 117-118).

(14) (Hutchison 1981:119)
a. Lâira
waajía
kslânǵm
nojâm
judgement day come.3sG.COND head.2sG know.2sG.FUT
'When judgement day comes you shall know yourself.'
b. kâm tawajía kâusoro kazóno
person get.up.early.3sG.COND heat.IO avoid.3sG.FUT
'The early riser shall avoid the heat.'

On dependence of MK future on preceding sentential elements Lukas (1937: 36) has the following to say: "The Future indicates futurity, but it is used mainly after conditional clauses, indicating that something will only take place if something else happens" (my italics). Schuh (1976: 14) assessing literature on Kanuri also notes the same property of the future tense: "Future...: A future event which is not certain to take place or which is dependent on some other event" (my italics).

Similar to $\mathrm{OKb}$ then, the past and future in MK share the same anaphoric property of referring to the antecedent element upon which the realisation of the event encoded in past/future is dependent.

In many MK dialects (Bilma, Dagəra, Manga, Mowar and Tumari) the past and future morphemes (underlying $k$ and $t$ respectively) are realised as homophones, warranting a unified term future/past (Jarrett \& Maman 2004: 16; see also Table 1). In these dialects, the anaphoric function of past and future seems to neutralise their temporal distinction, 
collapsing past and future under a single category of non-present. The temporal domain of this homophonous category is activated by syntactic or pragmatic mechanisms. e.g. in wh-question-answer situations referring to past time: "sawi issm? ['when did you come?'] bikka kadikko ['I came yesterday']" (ibid).

\section{Some parallels in Chadic languages}

As mentioned in the introduction, $\mathrm{OKb}$ and $\mathrm{MK}$ differ from other Saharan languages by much more complex TAM structures. The other Saharan languages Teda, Daza, Beria (Zaghawa) and (extinct) Berti largely operate with imperfective/perfective distinction (Lukas 1953; Cyffer 1998; Jakobi \& Crass 2004; Walters 2016) and have neither a specific argument focus form (AFP) nor elaborate past and future categories attested in $\mathrm{OKb}$ and MK. Such difference may well be explained by the contact Kanuri (and consequently $\mathrm{OKb}$ ) has had with Chadic languages since at least the $13^{\text {th }}$ century (inter alia Lange 1980; Tourneux 2008; Dewière 2012). As an outlier into the territories of (West) Chadic languages, Kanuri underwent contact-induced changes in lexicon and grammar (Schuh 2003; Cyffer 2002; Ziegelmeyer 2009).

Convincing evidence has also been educed that the elaboration of the Kanuri TAM system was triggered by contact with the West Chadic languages (Cyffer 2000; Wolff \& Löhr 2005). To what extent Chadic languages were responsible for the specific posterior, conditional and foregrounding semantics of the past and future tenses in MK is less clear. Nevertheless, some parallels in posterior-taxis organisation of discourse provided by past and future tenses are found, for example, in Miya (Schuh 1998) and Hausa (Jaggar 2001; 2006). Thus, the "conditional future" in Miya denotes events "posterior to a time of reference", frequently "following the expression of some kind of condition", with the time of reference located in present, or in the past (Schuh 1998: 137). Similar posterior and conditional semantics is attested in the uses of the future and allative tenses in 
Hausa (the allative being morphologically cognate with the future). The future may "be exploited with past-time reference to specify an event/action whose realisation is future relative to the established past reference time" (Jaggar 2001: 195). It is also used in the main clauses of conditional and adverbial constructions to express posterior events, e.g. 'as soon as you tell me, I'll come' (ibid, emphasis added) or 'you'll get a good job after you graduate' (Jaggar 2001: 196, emphasis added). In focus environments, the future "substitutes for the modal Subjunctive" (Jaggar 2001: 196). The allative category "can express future-in-the-future and future-in-the-past meanings" (Jaggar 2001: 199). ${ }^{5}$

As for the past tense/perfective categories, Jaggar's (2006) seminal re-evaluation of the Hausa focus/narrative perfective provides an important framework for a unified analysis of narrative and focus environments. His study reveals the semantic-pragmatic links between temporal/taxis properties of this TAM category and its focus function. Specifically, "fronted focus/wh- constructions and pivotal foregrounded portions of past-time narratives utilize the same specialized Perfective tense-aspect morphology because they achieve the same discoursepragmatic goals - they all supply the most communicatively prominent and focal new information." (Jaggar 2006: 102, emphasis in the original). By the same token, the focus property of verbal predicates (specifically for perfective aspect) has been well established as an overall characteristic of Chadic (Wolff 2003). In terms of taxis properties, the events and situations encoded by the Hausa focus/narrative perfective have posterior orientation, being positioned after the background events.

${ }^{5}$ The functional scope of the Hausa future and allative is much wider than posterior taxis and focus, and these categories can express a range of other temporal and modal meanings (Jaggar 2001: 193-200). However, unlike the OKb and MK absolute-relative future, these Hausa categories are essentially relative tenses since they occur freely in both the past and future domains. 


\section{Conclusion}

The discussed properties of the past and future in $\mathrm{OKb}$ and $\mathrm{MK}$ can be brought under two major interrelated functions: (1) indicating foregrounded events in temporal and causal relation to their antecedents and thus (2) framing focused entities of information structure. Thus, $\mathrm{ARP}$ and $\mathrm{ARF}$ of $\mathrm{OKb}$ are foregrounding devices which establish the prominence of the events on the temporal axis. In the past tense domain, ARP supplies prominent and new information which is dependent on or conditioned by the preceding events (background). In the future tense domain, ARF supplies the prominent information equally conditioned by preceding events. This finding corroborates a previously postulated hypothesis that past and future in MK are inherently focus categories (Wolff \& Löhr 2006). A similar set of TAM properties has been reported for some West Chadic languages which were in contact with MK and contributed to the elaboration of the latter's TAM system.

Thus, in line with Jaggar (2006)'s analysis of Hausa focus/narrative perfective, and consistent with MK data, the formula for both tenses in $\mathrm{OKb}$ can further be specified by highlighting the 'event' component (E) in bold, as follows: ARP $=$ R-E-S and ARP $=$ S-R-E. Both tenses establish prominence of the encoded event $(\mathbf{E})$ in their respective temporal domains (-S/S-).

Although $\mathrm{OKb}$ preserves Saharan features no longer present in $\mathrm{MK}$, its TAM system is significantly more elaborated than in the other Saharan languages and similar to the complex TAM in MK. Given that the complexity of the Kanuri TAM system was triggered by contact with Chadic languages and that $\mathrm{OKb}$ preserves linguistic structures going back to the period between about the $13^{\text {th }}$ and $16^{\text {th }}$ centuries, the semantic properties of the $\mathrm{OKb}$ past and future provide additional evidence of early Chadic influence on Kanuri.

\section{Acknowledgements}

I am grateful to two anonymous reviewers for their constructive comments and suggestions. All remaining errors are mine alone. 


\section{Abbreviations}

1, 2, 3-1, 2, 3 person

$\mathrm{ADV}$ - adverbial (operator)

AFP - argument focus perfecive

AG - agent noun

APPL - applicative

ARF - absolute-relative future

ARP - absolute-relative past

CAUS - causative

COND - conditional

DET - determiner

DO - direct object

FUT - future tense

GEN - genitive

INESS - inessive

IPFV - imperfective
IO - indirect object

MK - Modern Kanuri

$\mathrm{OKb}$ - Old Kanembu

OBJ - object marker

$\mathrm{OF}$ - o-form (in AFP/PST/FUT)

PASS - passive

PST - past tense

PL - plural

$\mathrm{PFV}-$ perfective

SG - singular

SBJ - subject marker

TAG - tag question

YM - the "Yerima Mustafa" manuscript

$\mathrm{VN}$ - verbal noun

2:72 etc. chapter and verse of the Qur'an

\section{References}

Abdel Haleem, Muhammad. 2005. The Qur'an: a new translation. Oxford: Oxford University Press.

Bondarev, Dmitry. 2005. In search of the Saharan inflectional verbal paradigms in Old Kanembu. Afrika und Übersee 88. 35-51. (Appeared in 2008.)

Bondarev, Dmitry. 2013a. Language change induced by written codes: a case of Old Kanembu and Kanuri dialects. In Wagner, Esther-Miriam \& Outhwaite, Ben \& Beinhoff, Bettina (eds.), Scribes as agents of language change, 291-323. Berlin - Boston: Mouton De Gruyter.

Bondarev, Dmitry. 2013b. Qur'anic exegesis in Old Kanembu: linguistic precision for better interpretation. Journal of Qur'anic Studies 15(3). 56-83.

Bondarev, Dmitry. 2014a. Multiglossia in West African manuscripts: a case of Borno, Nigera. In Quenzer, Jörg B. \& Bondarev, Dmitry \& Sobisch, Jan-Ulrich (eds.), Manuscript cultures: Mapping the field, 113-155. Berlin - Boston: Mouton De Gruyter. 
Bondarev, Dmitry. 2014b. Old Kanembu and Kanuri in Arabic script: phonology through the graphic system. In Mumin, Meikal \& Versteegh, Kees (eds.), The Arabic script in Africa: studies in the use of a writing system, 107-142. Leiden - Boston: Brill.

Comrie, Bernard. 1985. Tense. Cambridge: Cambridge University Press.

Cyffer, Norbert. 1973. Syntax des Kanuri. Hamburg: Helmut Buske Verlag. (Hamburger Philologische Studien 35.)

Cyffer, Norbert. 1998. Basic time relations in the Saharan verbal system. In Zima, Petr \& Tax, Vladimir (eds.), Language and location in space and time, 45-53. Munich: Lincom Europa.

Cyffer, Norbert. 2000. Areale Merkmale im TAM-System und der Syntax der Saharanischen Sprachen. In Voßen, Rainer \& Mietyner, Angelika \& Meißner, Antje (eds.), "Mehr als nur Worte ...”. Afrikanistische Beiträge zum 65. Geburtstag von Franz Rottland, 159-182. Cologne: Rüdiger Köppe.

Cyffer, Norbert. 2002. The Lake Chad: a new Sprachbund boundary? In Nicolai, Robert \& Zima, Peter. (eds.), Lexical and structural diffusion. Corpus, 27-43. Nice: Univ. de Nice. (Les Cahiers 1.)

Declerck, Renaat. 1995. Is there a relative past tense in English? Lingua 97. $1-36$.

Dewière, Rémi. 2012. Nommer l'autre : la représentation du monde au Sultanat du Kanem/Borno. In Baldi, Sergio \& Magrin, Geraud (eds.), Les échanges et la communication dans le bassin du Lac Tchad: Actes du colloque de Naples du réseau Mega-Tchad, 425-448. Naples: University of Naples.

Güldemann, Tom. 1998. The relation between imperfective and simultaneous taxis in Bantu: late stages of grammaticalization. In Fiedler, Ines \& Griefenow-Mewis, Catherine \& Reineke, Brigitte (eds.), Afrikanische Sprachen im Brennpunkt der Forschung, 157-177. Cologne: Rüdiger Köppe.

Jaggar, Philip J. 2001. Hausa. Amsterdam: John Benjamins. (London Oriental and African Language Library 7.)

Jaggar, Philip J. 2006. The Hausa perfective tense-aspect used in wh-/focus constructions and historical narratives: a unified account. In Hyman, Larry M. \& Newman, Paul (eds.), West African linguistics: Descriptive, comparative, and historical studies in honor of Russell G. Schuh, 100 133. London: J.M. Dent \& Co. 
Jakobi, Angelika \& Crass, Joachim. 2004. Grammaire du beria (langue saharienne). Cologne: Rüdiger Köppe.

Jakobson, Roman. 1984. Shifters, verbal categories and the Russian verb. In Russian and Slavic Grammar. Studies 1931-1981, 41-58. Berlin: Mouton De Gruyter.

Jarrett, Kevin Anthony \& Maman, Mallam Garba. 2004. Manuel de conjugaison kanuri. Niamey: Ministère de l'Education de Base 1 et de l'Alphabétisation, Edition Albasa.

Hutchison, John P. 1981. A reference grammar of the Kanuri language. Madison: University of Wisconsin; [Boston]: African Studies Center, Boston University.

Hyman, Larry M. \& Watters, John R. 1984. Auxiliary focus. Studies in African Linguistics 15(3). 233-273.

Lange, Dierk. 1980. La région du lac Tchad d'après la Géographie d'Ibn Sa'id. Annales islamologiques 16. 149-181.

Lukas, Johannes. 1937. A study of the Kanuri language. London: Oxford University Press.

Lukas, Johannes. 1953. Die Sprache der Tubu in der zentralen Sahara. Berlin: Deutsche Akademie der Wissenschaften, Institut für Orientforschung.

Maslov, Jurij S. 1988. Resultative, perfect, and aspect. In Nedjalkov, Vladimir P. (ed.), Typology of resultative constructions, 257-267. Amsterdam: Benjamins. (Typological Studies in Language 12)

Sahih International: https://quran.com.

Schubert, Klaus. 1971-1973. Zur Bedeutung und Anwendung der Verbalparadigmen im Hausa und Kanuri. Africa und Übersee 55 (1971/1972). 1-49, 208-227, 367-400. Africa und Übersee 56 (1972/1973). 90-118.

Schuh, Russell G. 1976. Kanuri Structure [with a focus on Manga Kanuri]. (Ms.)

Schuh, Russell G. 1998. A grammar of Mia. Berkeley: University of California Press.

Schuh, Russel. 2003. The Linguistic influence of Kanuri on Bade and Ngizim. Maiduguri Journal of Linguistic and Literary Studies (MAJOLLS) 5. 55-89.

Timberlake, Alan. 2007. Aspect, tense, mood. In Shopen, Timothy (ed.), Language typology and syntactic description. Vol. 3. Grammatical cate- 
gories and the lexicon. $2^{\text {nd }}$ edn., 280-333. Cambridge: Cambridge University Press.

Tourneux, Henry. 2008. Le nom des Sao: approche étymologique. Ms. http:// llacan.vjf.cnrs.fr/publications/Mega-Tchad_Le_nom_des_Sao.pdf

Wolff, H. Ekkehard. 2003. Predication focus in Chadic languages. In Wolff, H. Ekkehard (ed.), Papers in Chadic linguistics. From the 151 Biennial international colloquium on the Chadic language family, 137-159. Cologne: Rüdiger Köppe.

Wolff, H. Ekkehard. 2005. Intrinsic focus and focus control in two varieties of Hausa. In Voeltz, F.K. Erhard (ed.), Studies in African linguistics typology, 398-415. Amsterdam: John Benjamins.

Wolff, H. Ekkehard \& Löhr, Doris. 2005. Convergence in Saharan and Chadic TAM systems. Afrika und Übersee 88. 265-299. (Appeared in 2008.)

Wolff, H. Ekkehard \& Löhr, Doris. 2006. Encoding focus in Kanuri verbal morphology: Predication focus and the "Kanuri focus shift". In Fiedler, Ines \& Schwarz, Anne (eds.), Papers on information structure in African languages, 185-209. Berlin:Zentrum fürAllgemeineSprachwissenschaft. Walters, Josiah K. 2016. A grammar of Dazaga. Boston: Brill.

Ziegelmeyer, Georg. 2009. Areal features in Northern Nigeria - towards a linguistic area. In Zima, Petr (ed.), The verb and related areal features in West Africa: continuity and discontinuity within and across Sprachbund frontiers, 269-306. Munich: LINCOM Europa. 